\title{
Arıtma Çamurlarının Toprakta Alınabilir Kurşun ve Dehidrogenaz Enzim Aktivitesi Üzerine Etkileri
}

\author{
Ayten KARACA ${ }^{\top}$ \\ Koray HAKTANIR'
}

Geliş Tarihi: 10.01 .2000

\begin{abstract}
Özet: Bu araştırmada, Izmit DUSA (Endüstriyel Iplik Üretimi) ve SEKA (Kağıt ve Selöloz Üretimi) fabrikalarının atık su arıtma țesislerinde ortaya çıkan arıtma çamurlarınin İmit Alikahya Köyün'den alınan tarım toprağının alinabilir kurșun $(\mathrm{Pb})$ ve dehidrogenaz enzim aktivitesi lizerinde yapmıs olduğu etkiler araștırımıștır. Bu amaçla, laboratuarda hazırlanan toprak-çamur karışımları tarla kapasitesinin \% $70^{\prime}$ k kadar nemlendirilerek $28^{\circ} \mathrm{C}$ 'de inkobasyona alınmıștır. Belirli oranlarda atık çamur örnekleri uygulanmıs (kontrol, 20, 40, 80, 160 tonha $^{-1}$ ) toprak örneklerinde, alınabilir Pb 1., 5., 15., 30, 60., 120. ve 240. gün olmak uzere 7 inkübasyon dörieminde, dehidrogenaz aktivitesi de 1., 3., 7., 14., ve 30. gün olmak üzere 5 inkübasyon döneminde belirlenmiștir.

Íki atık çamurunun farkı dozlarının topraklara uyguianmasıyla alınabilir Pb kapsamında önemli artıșların bulünduğu belirlenmiş olup $(P<0.01)$, SEKA çamuru ilave edilmiş toprakların alınabilir $\mathrm{Pb}$ kapsamındaki artışın DUSA çamuruna göre tǘm dozlarda fazla olduğu saptanmıştır.

DUSA ve SEKA çamurları dehidrogenaz aktivitesini farkit etkilemiştir. Her iki çamurun yüksek dozlarda ilave edildiği topraklarda dehidrogenaz aktivitesi artış göstermiş olup, bu artışın DUSA çamurunda daha fazla olduğu belirlenmiştir. DUSA çamuru ilave edilmiş topraklarda dehidrogenaz aktivitesi SEKA çamuruna göre daha fazla belirlenmiştir. DUSA çamuru ilave edilmiş topraklarda inkubasyonun 30 . gününde 160 tonha $a^{-1}$ çamur dozunda dehidrogenaz aktivitesi 55.56 $\mu$ TPF $\mathrm{g}^{-1}$ olarak bulunmușken, aynı inkübasyon süresi ve aynı dozda liave edilmiş SEKA çamurunda aktivite 38.90 $\mu \mathrm{gTPF} \mathrm{g}^{-1}$ olarak belirlenmiștir.
\end{abstract}

Anahtar Kelimeler: Aritma çamuru, toprak, alinabilir kurșun, dehidrogenaz aktivitesi

\section{Effects of Sewage Sludges on Available Lead and Dehydrogenase Enzyme Activity in Soil}

Abstract: In this research, effects of these sludges of DUSA (Industriai Yarn Manufacturing) and SEKA (Paper and Cellulose Production) on soil available lead and dehydrogenase activity in soil, taken from Izmit Alikahya village, were searched. For this purpose, soil-sludge mixtures were kept at $70 \%$ field capacity during incubation period at $28^{\circ} \mathrm{C}$. Applied waste sludge $\left(0,20,40,80\right.$ and 160 tonha $\left.^{-1}\right)$ soil samples were analyzed at 7 different incubation periods $(1,5 ., 15 ., 30$., $60 ., 120 ., 240$.) to determine available $\mathrm{Pb}$ and 5 different incubation periods $(1 ., 3 ., 7 ., 14$, ve 30 .) to determine dehydrogenase activity.

Applying of both sludges have significantly increased available $\mathrm{Pb}$ content in the soil $(\mathrm{P}<0.01)$, However, that increasing in soil applied SEKA sludge was higher than applied DUSA sludge in all doses.

The effects of DUSA and SEKA sludges on dehydrogenase activty are different. Dehydrogenase activities were increased in high doses of both sludges, especially in DUSA sludge. Dehydrogenase activity of soil applied DUSA and SEKA were found $55.56 \mu \mathrm{gTPF} \mathrm{g}^{-1}$ and $38.90 \mu \mathrm{gTPF} \mathrm{g}^{-1}$ at dose of 160 tonha $\mathrm{g}^{-1}$ in $30^{\text {th }}$ day, respectively.

Key Words: Sewage sludge, soil, available lead, dehydrogenase activity

\section{Giriş}

Arıtma çamuru meydana geldiği endustriyel kuruluşun çeşidine göre, içinde organik bileşikler, asitler, alkaliler, metal tuzian $(\mathrm{Hg}, \mathrm{Cd}, \mathrm{As}, \mathrm{Co}, \mathrm{Pb}, \mathrm{Cr} \mathrm{vb}$.$) ,$ fenoller, organik fosfor, azot gibi maddeler ve bileşikler içerebilmektedir (Karpuzcu, 1991).

Arıtma çamurları içeriklerine bağlı olarak toprakların ağır metallerce bulaşmasına, organik mikro kirleticilerin topraklara ulaşmasına neden olarak toprak kirliliği yaratmaktadir. Bu çamurlar içerdikleri bitki besin maddesi miktarına bağlı olarak toksisite ve yeraltı sularının kirtenmesine neden olabilmektedirler. Aritma tesislerinde oluşan çamurlar değişik işlemlerden geçirildikten sonra toprağa verilmekte, denize deşarj edilmekte, dolgu materyali olarak kullanılmakta veya yakılmaktadır. Arıtma çamurlarının çevreye en az zarar verecek biçimde bertarafı ve içerdikleri besin elementlerinin madde dolanımına sokulmasi amacıyla araziye verilmesi en uygun yôntem olarak daşunúlse de, bunların topraklara ve yeraltı sularına yapabileceği etkileri araştırmak ve buna göre arazide bertarafına karar vermek gerekir (Turalıoglu ve Erdin, 1990)

\footnotetext{
'Ankara Üniv. Ziraat Fak. Toprak Bölumú- Ankara
} 
Aritma çamurunun tarimda kullanimi ile ilgili olarak Avrupa Topluluğu 1986 yilinda bir yönerge yayınlamıştır. Bu yönergede, Avrupa'daki farklı iklim ve coğrafik ozeilikler dikkate alınarak toprakta bulunabilecek ağır metallerin azami konsantrasyonlari verilmektedir. Aritma çamurlarının tarımda kullaniminın artması bu amaçla kullanılabilecek çamurların, ozellikle ağır metaller younúnden daha sıki standartlara tabi tutulmasını beraberinde getirmiștir

Donyada arıtma çamuriarının tarımda değerlendirilmesi konusunda onemli çalışmalar yapilifken olkemizde henuz yeterli çalısmanin bulunduğunu soylemek zordur, Ozellikle son aşamada çamurun uzaklaştırma sistemlerinin maliyeti dôşunualdugüunde alkemiz gibi gelișmekte olan bir alkede bu tip pahalı çözümler yerine çamurun tarim alanlarında kullanimi en uygun çözümlerden biri olarak karşımıza çıkmaktadir (Akça ve ark., 1996).

Tanm alanlarında çamurun kullanımı bazı sorunları da beraberinde getirmektedir.Yuksek miktarlarda iz element içeren arıtıma çamurlarının toprakların mikrobiyal aktiviteleri uzerine etkileri konusunda pek çok çalişma yapilmıştir (Band ve ark, (1976): Liang ve Tabatabai, (1977): Frankberger ve ark., (1983)). Arıtma çamurlarinin toprakların enzim aktiviteleri uzerine etkileri, örnegin Ureaz aktivitesi (Tabatabal, 1977), fosfataz aktivitesi (Juma ve Tabatabai, 1977), arylsülfataz aktivitesi (AIKhafaji ve Tabatabai, 1979), amidaz aktivitesi (Frankberger ve Tabatabai, (1981), glikozidaz aktivitesi (Eivazi ve Tabatabai, 1990; Eivaza ve Zakaria, 1993) ve dehidrogenaz aktivitesi (Reddy ve Faza, 1988) uzerine etkileri konusunda da araştırmalar bulunmaktadır.

Toprakta mikroorganizmaların biyolojik aktivitaleri ile flgili bilgi edinmenin en çabuk yolu katalaz ve dehidrogenaz aktivitesini tespit etmektir, Çonko her iki enzim de ağir metallere karşı çck hassas (Naplekova ve Bulavko, 1983; Perez ve Gonzalez, 1987; Wilke, 1991) ve çabuk ve kolay yöntemler lie tespit edilebilmektedir (Rogers ve Li, 1985).

Toprak kıriliaginden sorumlu çeșitli inorganik kokenli elementlerin yanısıra, $\mathrm{Cd}$ ve $\mathrm{Pb}$ gibi ağir metaller en onemli yeri tutmaktadir. cunko bu metaller topraga değişik yollaria girmekte ve mikroorganizmalar tarafından tahrip edilmeden uzun yillar toprakta kalmakta ve biyolojik aktiviteleri en fazla etkileme ozelliğine sahip olmaktadirlar (Blum, 1989).

Ülkemizde arıtma çamurlarının tarımda kulianıIması Katı Atıklarin Kontrolo Yōnetmeliği ile düzenlenmiştı. Bu yönetmelikte arıtma çamurlannın kulianma sınırlamaları ve yasakları belirtilmiştir. Tarımda kullanilacak arıtma çamurunda ve toprakta müsaade edilen ağır metal içerikleri Çizelge 1'de verilmiștir. Olkemizde arıtma çamurlarinin ne şekilde uzaklaştirilacağına dair yayınlanmiş verijer bulunmadı̊ından arıtma çamurlarının tarım alanlarında kullanım orani bilinmemektedir. Ancak olkemizde aritma tesislerinin sayısınin artmasiyla birlikte artan aritma çamurlarinin bertarafinda lik akla gelen, tarim, şehir ve endustrinin içice geçmiş olduğu bölgelerde farım alanlarında kullanımıdır. Bu nedenle bu çalıșmada,
Çizelge 1. Tanmda Kullanilacak aritma camurunda ve toprakta mosaade edilen ağır metal içerikjeri (Katı atıkdarin kontrolà yönetmeliğı, 1991)

\begin{tabular}{|ccc|}
\hline Ağir metal & Sinir deger & \\
\hline mgkg & Aritma famurs & Toprak \\
$\mathrm{Pb}$ & 1200 & 100 \\
$\mathrm{Cd}$ & 20 & 3 \\
$\mathrm{Cr}$ & 1200 & 100 \\
$\mathrm{Cu}$ & 1200 & 100 \\
$\mathrm{Ni}$ & 200 & 50 \\
$\mathrm{Hg}$ & 25 & 2 \\
$\mathrm{Zn}$ & 3000 & 300 \\
\hline
\end{tabular}

ülkemizin hem endüstriyel, fiem de tarimsal yönden en çok goze çarpan bölgelerinden biri olan lzmit ili seçilmiştir. Bu bálge tarım ile endustrinin içice geçtigi bir belige olarak çok çeşitll kirlilik sorunlanyla karşı karsıyadir.

Bu araştirmada, topraklara verildiğinde ciddi toprak kirliliği sorunları yaratmayacağı dussunulen ve gübrelemeye alternatif olabilecek duzeyde bitki besini içeren aritma çamuruna sahip ve çamurlarin ağir metal içeriği Katı Atikların Kontrolü Vonetmeliğinde belirtilen ağir metal limit değerini aşmayan SEKA ye DUSA tesislerinin arıtma çamurlar! seçilmiştir. Bóylece topraklara uygulanmasinda mevzuata göre engel olmayan çamurların toprakta alinabilir kurşun miktarı ve toprak biyolojik parametrelerinden Dehidrogenaz enzim aktivitesi uzerine etkisi ve en uygun uygulama dozu 240 günlük bir periyot da izlenmiştir.

\section{Materyal ve Yöntem}

Araştırmada kullanılan toprak ơrneği Izmit- Allkahya kōyūnden ve $0-20 \mathrm{~cm}$ derinlikten alinmiștır. Antma çamuru materyall olarak ise SEKA Izmit Kağit Fabrikasi arıtma tesisi ve DUSA Endustriyel Iplik Oretim Fabrikası arıtma tesisinden ६̧ikan arıtma çamurları kullanilmıştır.

\section{Inkübasyon denemesi}

lki farklı aritma çamurunun deneme süresi boyunca toprakların alınabilir $\mathrm{Pb}$ miktarlan ile dehidrogenaz enzim aktivitesi Qzerindeki etkinliğini saptamak amaciyla kurulan inkübasyon denemesi 5 SEKA çamuru, 5 DUSA çamuru konulu, 3 yinelemeli ve alınabilir $\mathrm{Pb}$ için $1 ., 5$. 15. 30, 60, 120, ve 240. gon olmak uzere 7 inkubasyon doneminde, dehidrogenaz aktivitesi için de $1,3,7,14 .$, ve 30. gün olmak uzere 5 inkúbasyon döneminde tesadüf parselleri deneme deseninde yurutülmaştur.

\section{Deneme konular!}

A. Kontrol, B. 20 tonha ${ }^{-1}$ çamur, C: 40 tonha ${ }^{-1}$ çamur, D: 80 tonha $^{-1}$ camur, E: 160 tonha ${ }^{-1}$ camurdur. $400 \mathrm{~cm}^{3}$ hacimli plastik kaplarda mutlak kuri madde ilkesine goie $200 \mathrm{~g}$. toprak materyaline yukarıda belirtilen düzeylerde iki farklı aritma çarnurlarindan ilave edilmiştir. Karışim toprakları tarla kapasitesinin \% $70^{\prime} i$ oranında nemlendirilmiş, plastik kaplar streçlenerek $28^{\circ} \mathrm{C}$ 'ye ayarlı inkabatörde inkübasyona alinmıștıt. $1,5,15,30,60,120$ ve 240 günluk inkubasyon sürelert sonunda alinabilir $\mathrm{Pb}$ ve $1,3,7,14$ ve 30 gunlak inkübasyon süreleri sonrasinda da dehidrogenaz aktivitesi belirlenmiștic. 
Denemede kullanilan toprak orneği $2 . \mathrm{mm}$ den elenmiş, kurutuimuş ve gravimetrik olarak nem tayini yapilmıştır. Fabrikalardan alınan camur rrnekleri laboratuvara getirildikten sonra kurutulup $2 \mathrm{~mm}$ 'den elenerek analize hazır hale getirilmiştir.

\section{Toprak örneklerinin analizi}

Toprak örneğinde tarla kapasitesi Richarós (1954) 'в göre, solma noktasi Richards (1949)a gore 15 atm basınca dayaniklı seramik levha kullanilarak hacim ağırliğ De Boodt ve ark. (1973)'e göre bozulmuş toprak orneğinde, organik madde Jackson (1962)'e gore Walkey-Black yőnteminin modifiye edilmiş şekli ile, EC ve $\mathrm{pH}$ Richards (1954)'e göre saturasyon ekstraktından biçulerek, toplam $\mathrm{N}_{1} \mathrm{NH}_{4}{ }^{+}-\mathrm{N}$ ve $\mathrm{NO}_{3}{ }_{3}-\mathrm{N}^{\prime} \mathrm{u}$ Bremner (1965) Kjeldahl yountemine gore, $\mathrm{C} / \mathrm{N}$ oranı hesap yolu ile bulunan organik karbonun, belirlenen $\mathrm{N}$ miktarına bolunmesiyle, KDK ve serbest iyonlar Richards (1954)'e góre, değişebilir katyoniar Börekçi (1991)'e góre, \% karbonat Çağlar (1958) metoduyla, tane bouyokloğo dağllimı Bouyoucus (1951)'a gore, toplam P Kacar (1996)'a gơre perklorik asit çozeltisi ile yaş yakma metoduyla, yarayışlı P Kacar (1990) tarafından bildirildiği şekilde $0.5 \mathrm{M} \mathrm{NaHCO}$ çozeitisi kullanilarak ekstrakte edilmis olup vanado molibdo san renk esasina göre spektrometrede belirlenmiştir.

Her inkubasyon donemi sonunda belirlenen alinabilir $\mathrm{Pb}$, Lindsay ve Norvell (1978) tarafindan belirtildigi şekilde $0.005 \mathrm{M}$ DTPA ve $0.1 \mathrm{M}$ kalsiyum kloror çözeltisi ile ekstrakte edilip AAS' de grafit firn kullanilarak belirlenmiştir. Her inkubasyon dónemi sonunda belirlenen dehidrogenaz enzim aktivitesi ise, Beyer ve ark. (1993) tarafindan belirtildiğ şekilde $5 \mathrm{~g}$ toprak orneği TTC-TRis buffer kullanilarak ekstrakte edilmis, ekstrakiar 24 saat 30 $C^{\prime}$ de karanlikta inkobe edilmiş. $20 \mathrm{ml}$ aseton $1 \mathrm{le} 2$ saat calkalandiktan sonra $485 \mathrm{~nm}$ dalga boyunda spektrofotometrik olarak tayin edilmiştir

\section{Çamur örneklerinin analizi}

DUSA ve SEKA fabrikalarinin atik su aritma tesislerinden alinan aritma camuru orneklerinde $\mathrm{pH}, \mathrm{EC}$, organik madde, kirec, toplam $\mathrm{N}_{1} \mathrm{NH}_{4}{ }^{+}-\mathrm{N}$ ve $\mathrm{NO}_{3}{ }^{-}-\mathrm{N}^{\prime} \mathrm{u}$, toplam ve yarayışı $P_{1}, K D K$ serbest iyonlar, değișebilit katyonlar, organik C, C/N oranı, \% nem, hacim ağırlığı, tarla kapasitesi ve solma noktasi toprak orneklerinde belirtildiği sekilde belirlenmiştir. SEKA çamuru ağır metal değerleri Eroğlu ve ark. (1990) ve DUSA çamuru ağır metal değerleri Geveci (1995) tarafindan belirlenmiştir.

Laborauvar analizleri sonunda elde edilen verilerin istatistiki analizleri Yurtsever (1984)'e gore yapilmıştır.

\section{Bulgular ve Tartışma}

Denemede kullanilan toprak ve arıtma çamur orneklerinin fiziksel ve kimyasal bzellikleri Çizeige 2'de, toplam ve alınabilir ağir metal ve iz element değerleri de Cizelge 3'de verilmiştir.

\section{SEKA ve DUSA çamurlannın toprağın alınabilli $\mathrm{Pb}$ kapsami Uzerindeki etkileri}

SEKA ve DUSA çamurlarının farklı dozlannın 240 günlok inkübasyon süresi boyunca toprakların alınabilir $\mathrm{Pb}$ kapsamı ozerine etkileri ve buna ait istatistiksel değerlendirmeler Çizelge 4 'de verilmiştir. Cizeigeden de anlaşılacağı uzere, 2 atık çamurunun farkh dozlarinin topraklara uygulanmasiyla topraklarin alınabilir Pb kapsaminda onemli artışların bulunduğu belifienmiştir $(P<0.05)$. Bu artişlarin dozlara ve inkubasyon saresine (kontrol topraklan hariç) bağll olarak gerçekleștiğl ve en fazla alinabilir Pb kapsaminin 160 ton ha gunde gerçakleştiği beliflenmiștir.

SEKA çamuru ilave edilmiş topraklarda inkübasyonun 1. gana, kontrol ile ilk 3 uygulama dozunun alınabilir $\mathrm{Pb}$ miktari Qzerindeki etkisi istatistiksel olarak onemfi bulunmazken, son doz olan 160 tonha ${ }^{-1}$ lik çamur ilavesi alınabilir $\mathrm{Pb}$ miktarını artirmıştır $(P<0.05)$. Inkabasyonun diğer zamanlarinda ise kontrole gôre 4 farklı dozda ilave odilen çamur, artan doza bağlı olarak toprakların alınabilir $\mathrm{Pb}$ kapsamını artırmiştır $(\mathrm{P}<0.05)$.

DUSA camuru ilave exilmiş topraklarda inkubasyonun 1, gana, kontrol ile 4 farkd dozda ilave edilmiş çamur ömeklerinin alınabilir $\mathrm{Pb}$ miktarı ozerindeki etkisi istatistiksel olarak onemli bulunmazken, inkobasyonun $S$ ve 15. günlerinde ise 160 ton ha ${ }^{-11 / 1 k}$ camur ilavesi alınabilir $\mathrm{Pb}$ miktarını artırmıştır $(P<0.05)$. inkübasyonun 60., 120. ve 240. gunlerinde ise kontrole göre artan dozlarda ilave edilen DUSA çamuru topraklarin alınabilir $\mathrm{Pb}$ kapsamini artırmiştır $(P<0,05)$,

Iki atık çamurunu kıyasladığımızda, SEKA çamuru llave edilmis topraklarin alınabilir $\mathrm{Pb}$ kapsamındaki artişın DUSA çamuruna góre tom dozlarda fazla olduğu saptanmıștir. Kontrole oranla topraklarin alinabilir $\mathrm{Pb}$ miktarlarindaki değișim yüzdelerine bakıldığında, SEKA çamuru ilave edilmiş topraklarda en fazla \% değişim inkobasyonun 240. gonünde ve 160 ton ha" dozunda \% 2710.3 olarak gerçekleşmiş, DUSA çamurunda ise yine en fazla değisim 240. günde ve 160 ton ha $a^{-11}$ lik çamur dozunda ancak \% 1598.1 olarak gerçekleşmiştir.

Akther (1990), bir yil sure ile ortalama olarak 150 $\mathrm{mgkg}^{-1} \mathrm{~Pb}, 7.5 \mathrm{mgkg}^{-1} \mathrm{Cd}, 50 \mathrm{mgkg}^{-1} \mathrm{Ni}, 370 \mathrm{mgkg}^{-1} \mathrm{Cu}$ ve $600 \mathrm{mgkg}^{-1} \mathrm{Zn}$ içeren arıtma çamuru ilave ettiği toprakların $\mathrm{Pb}, \mathrm{Cd}, \mathrm{Ni}, \mathrm{Cu}$ ve $\mathrm{Zn}$ dağılimini araştırdiğı çalışmasında, aritma çamuru llavesi sonucu topraklarda ozellikle $\mathrm{Pb}$ ve $\mathrm{Cd}$ miktarlarinda onemii artışların oldugunu belirtmiştir.

Williams ve ark. (1987), ağır metal içerikleri doşuk ve yojksek olan iki farkli aritma çamurunu topraklara llave etmis ve 9 yil sure ile ağir metallerin toprak profilindeki dağlimını ve toplam ve alınabilir ağır metal miktarlarındaki değişimleri izlemişlerdir. Araştırmacılar, yüksek miktarda ağır metal içeren çamur llave edilmiş topraklarda \% 1 dozeyinde oriemili ağır metal artısłarınin olduğunu, aği metal dağiliminin da toprak profili boyunca değişim gosterdiğini belirtmişlerdir. 
Çizelge 2. Araştırma toprağının ve çamur örneklerinin bazı fiziksel ve kimyasal özellikleri

\begin{tabular}{|c|c|c|c|c|c|c|c|c|c|}
\hline Örnek & $\begin{array}{c}\mathrm{pH} \\
(1: 2.5)\end{array}$ & Ec d Sm & $\mathrm{CaCO}_{3}, \%$ & $\begin{array}{c}\text { Organik madde, } \\
\%\end{array}$ & $\begin{array}{c}\text { Organik karbon } \\
\%\end{array}$ & $\begin{array}{c}\text { Toplam azot, } \\
\%\end{array}$ & $\mathrm{C} / \mathrm{N}$ & $\begin{array}{l}\mathrm{NH}_{4}^{+}-\mathrm{N} \\
\mathrm{mgkg}^{-1}\end{array}$ & $\begin{array}{l}\mathrm{NO}_{3}=\mathrm{N} \\
\mathrm{mgkg}^{-1}\end{array}$ \\
\hline Toprak & 7.91 & 1.02 & 1.46 & 13.99 & 6.99 & 0.74 & 9.37 & 1816 & 150.6 \\
\hline SEKA Çamuru & 7.27 & 2.54 & 0.147 & 48.77 & 24.38 & 1.14 & 21.38 & 927.66 & 401 \\
\hline DUSA Çamuru & 7.10 & 10.91 & 1.46 & 68.33 & 34.16 & 3.26 & 10.47 & 2120 & 905.66 \\
\hline
\end{tabular}

\begin{tabular}{|c|c|c|c|c|c|c|c|c|c|c|}
\hline Órnek & Toplam & Yarayıșil & KDK & Değișe & i katyc & me $100 \mathrm{~g}^{\circ}$ & & & ekstûr & \\
\hline Toprak & 2605 & 293.25 & 34.62 & $\begin{array}{l}\mathrm{Na}^{+} \\
0.58\end{array}$ & $\begin{array}{c}K \\
7.51\end{array}$ & $\begin{array}{c}\mathrm{Ca}^{+1}+\mathrm{Mg} \\
26.52\end{array}$ & $\begin{array}{l}\text { Kum } \\
28.4\end{array}$ & $\begin{array}{l}\text { Silf } \\
29.2\end{array}$ & $\begin{array}{l}\mathrm{Kit} \\
42.4\end{array}$ & $\underset{C}{\text { Sinifi }}$ \\
\hline SEKA çamuru & 301.10 & 181.60 & 179.03 & 4.31 & 2.13 & 172.26 & - & - & - & - \\
\hline DUSA çamuru & 2600.30 & 433.46 & 51.91 & 6.86 & 5.52 & 39.53 & - & - & - & - \\
\hline
\end{tabular}

Çizelge 3. Araştırmada kullanılan SEKA ve DUSA çamurlarının ağır metal miktarları

\begin{tabular}{|c|c|c|c|c|}
\hline Parametre & SEKA gamurL & & DUSA camuru & \\
\hline (mgkg ${ }^{-1}$ kuru camur) & Toplam & Alinabilit & Toplam & Alınabilir \\
\hline $\mathrm{Pb}$ & 77 & 1.43 & 19.2 & 0.79 \\
\hline $\mathrm{Zn}$ & 310 & 91.05 & 200 & 43.07 \\
\hline $\mathrm{Fe}$ & 2950 & 97.00 & 3200 & 62.00 \\
\hline $\mathrm{Cu}$ & 220 & 39.25 & 276 & 79.97 \\
\hline
\end{tabular}

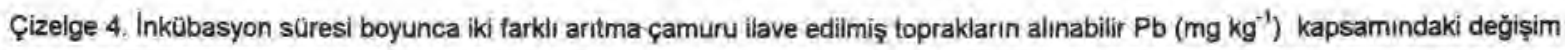

\begin{tabular}{|c|c|c|c|c|c|c|}
\hline & Gün & Kontrol & 20 tonha $a^{-1}$ & 40 tonha $a^{-1}$ & 80 tonha $^{-1}$ & 160 tonha ${ }^{-1}$ \\
\hline \multirow[t]{7}{*}{ SEKA } & 1. & $0.395 \mathrm{~B} \mathrm{a}$ & $0.443 \mathrm{~B} \mathrm{~b}$ & $0.466 \mathrm{BC}$ & $0.483 \mathrm{~B} \mathrm{C}$ & $0.643 \mathrm{Ae}$ \\
\hline & 5. & $0.388 \mathrm{C}$ a & $0.446 \mathrm{BC} \mathrm{b}$ & $0.488 \mathrm{~B} \mathrm{C}$ & $0.516 \mathrm{~B} \mathrm{C}$ & $0.975 \mathrm{Ad}$ \\
\hline & 15. & $0.376 \mathrm{Da}$ & $0.491 \mathrm{Cb}$ & $0.545 \mathrm{Cb}$ & $0.683 \mathrm{~B} \mathrm{C}$ & $1.156 \mathrm{Ad}$ \\
\hline & 30. & $0.375 \mathrm{E}$ a & $0.566 \mathrm{D} \mathrm{b}$ & $0.770 \mathrm{Cb}$ & $1,136 \mathrm{~B} \mathrm{~b}$ & $1.816 \mathrm{Ad}$ \\
\hline & 60. & $0.339 \mathrm{E} \mathrm{a}$ & $0.650 \mathrm{Db}$ & $0.835 \mathrm{cb}$ & $1403 \mathrm{~B} \mathrm{~b}$ & $2.583 \mathrm{AC}$ \\
\hline & 120. & $0.349 \mathrm{E}$ a & $0.719 \mathrm{Da}$ & $1.776 \mathrm{Ca}$ & $2.263 \mathrm{~B} \mathrm{a}$ & $3.94 \mathrm{~A} \mathrm{~b}$ \\
\hline & 240. & $0.323 \mathrm{E} \mathrm{a}$ & $0.816 \mathrm{Da}$ & $1.960 \mathrm{C} \mathrm{a}$ & $2.880 \mathrm{~B} \mathrm{a}$ & $5.07 \mathrm{Aa}$ \\
\hline \multirow[t]{7}{*}{ DUSA } & 1. & $0.395 \mathrm{~A} a$ & $0.391 \mathrm{~A} \mathrm{~b}$ & $0.420 \mathrm{Ab}$ & $0.456 \mathrm{AC}$ & $0.510 \mathrm{Ad}$ \\
\hline & 5. & $0.388 \mathrm{~B} \mathrm{a}$ & $0.378 \mathrm{~B} \mathrm{~b}$ & $0.423 \mathrm{~B} \mathrm{~b}$ & $0.483 \mathrm{~B} \mathrm{C}$ & $0.646 \mathrm{Ad}$ \\
\hline & 15. & $0.376 \mathrm{Ca}$ & $0.385 \mathrm{Cb}$ & $0.440 \mathrm{BC} \mathrm{b}$ & $0.503 \mathrm{BC}$ & $0.853 \mathrm{~A} \mathrm{C}$ \\
\hline & 30 & $0.375 \mathrm{Ca}$ & $0.425 \mathrm{C} \mathrm{a}$ & $0.471 \mathrm{Cb}$ & $0.770 \mathrm{~B} \mathrm{C}$ & $0.923 \mathrm{AC}$ \\
\hline & 60 & $0.339 \mathrm{E} \mathrm{a}$ & $0.479 \mathrm{D} \mathrm{a}$ & $0.590 \mathrm{Ca}$ & $0.855 \mathrm{~B} \mathrm{~b}$ & $1,076 \mathrm{AC}$ \\
\hline & 120. & $0.349 \mathrm{E} \mathrm{a}$ & $0.500 \mathrm{Da}$ & $0.717 \mathrm{Ca}$ & $1.223 \mathrm{~B} \mathrm{~b}$ & $1.893 \mathrm{~A} \mathrm{~b}$ \\
\hline & 240. & $0.323 \mathrm{E}$ a & $0.726 \mathrm{Da}$ & $0.926 \mathrm{Ca}$ & $1.86 \mathrm{~B} \mathrm{a}$ & $3.48 \mathrm{Aa}$ \\
\hline
\end{tabular}

SEKA çamuru için LSD (\%5): 0.305

DUSA çamuru için LSD (\%5): 0.382

Büyük harfler uygulama dozları arasindaki iliş̧i (yatay), küçük harfler inkübasyon dönemleri arasindaki ilişkiyi (dúşey) göstermektedir.

O'Riordan ve ark. (1994), düşak miktarlarda $\mathrm{Cu}_{i} \mathrm{Zn}$ ve $\mathrm{Pb}$ içeren aritma çamurunun toprağa ilavesi sonucu 3 yıl sure ile toprakların toplam ve alınabilir $\mathrm{Cu}, \mathrm{Zn}$ ve $\mathrm{Pb}$ miktarlarındaki değişimi araştırmışlardır. Araştırmacılar, 3 yil süre ile ve yilda $3 \mathrm{kez}$ olmak üzere 25,50 ve 75 $\mathrm{m}^{3} \mathrm{ha}^{-1}$ çamuru toprağa ilave etmişler, ilk yil toplam ve alınabilir metal miktarlarındaki artışın ơnemli olmadığını ancak, 1. yildan sonra topraktaki $\mathrm{Zn}, \mathrm{Cu}$ ve $\mathrm{Pb}$ 'nin gerek toplam ve gerekse alınabilir miktarlarında önemli artışların olduğunu belirtmişlerdir.

Bu veriler ve çalışmamızdaki sonuçlar birlikte değerlendirildiğinde ağır metal içeriği literatürlerde görülen örneklerden daha duşak olan bir çamur uygulamasında bile özellikle doz ve zamana bağli olarak alınabilir $\mathrm{Pb}$ düzeylerinde çok önemli artışlar saptanması uzun vadeli kullanımlar söz konusu olduğunda toprak sisteminde ve alınabilir formda $\mathrm{Pb}$ olasılığını kuvvetle ortaya koymaktadir.

\section{SEKA ve DUSA çamurlarının toprağın} dehidrogenaz enzim aktivitesi uzerine etkileri

SEKA ve DUSA çamurlarının farklı dozlarının 240 günlük inkübasyon süresi boyunca toprakların dehidrogenaz aktivitesi úzerine etkileri ve buna ait istatistiksel değerlendirmeler Çizelge 5 'de verilmiştir. Çizelgeden de anlaşılacağı üzere, 2 atık çamurunun farklı dozlarinin topraklara uygulanmasiyla topraklarin dehidrogenaz enzim aktivitelerinde önemli değişimlerin olduğu belirlenmiştir $(P<0.05)$.

SEKA çamuru ilave edilmiş topraklarda inkübasyonun 1. ve 5 . günlerinde, artan doz miktarına bağlı olarak toprakların dehidrogenaz aktivitesi azalmıştır $(P<0.05)$. Inkübasyonun 7. ganünden titibaren son inkübasyon günône kadar ( 30 gün) 20 ve 40 tonha ${ }^{-1}$ çamur ilave edilmis topraklarda aktivite kontrole oranla azalmaya devam ederken, 80 tonha $^{-1}$ ve 180 tonha $^{-1}$ 


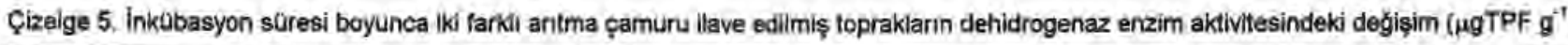

\begin{tabular}{|c|c|c|c|c|c|c|c|}
\hline & Goin & Kontrol & 20 tonha & 40 tonha ${ }^{-1}$ & 80 tonha & 160 tonha ${ }^{-1}$ & \\
\hline \multirow[t]{5}{*}{ SEKA } & 1. & $54.66 \mathrm{AC}$ & 37.538 a & $3105 \mathrm{Ca}$ & 29.7000 & $25.60 \mathrm{Ed}$ & \\
\hline & 3. & $63.96 \mathrm{Aa}$ & $36.60 \mathrm{Ba}$ & $2970 \mathrm{Ca}$ & $27.72 \mathrm{Dd}$ & $23.93 \mathrm{Ed}$ & \\
\hline & 7: & $61.30 \mathrm{Ab}$ & $13.72 \mathrm{Cb}$ & $11.09 \mathrm{Db}$ & $29.90 \mathrm{BC}$ & $29.76 \mathrm{~B} \mathrm{C}$ & \\
\hline & 14. & $59.76 \mathrm{Ab}$ & $10.33 \mathrm{Dc}$ & $6.98 \mathrm{EC}$ & $32.72 \mathrm{Cd}$ & 38.60 日 c & \\
\hline & 30. & $45.00 \mathrm{Ad}$ & $7.53 \mathrm{Dd}$ & $5.36 \mathrm{Ec}$ & $34.90 \mathrm{C}$ a & $38.90 \mathrm{~B}$ a & \\
\hline \multirow[t]{5}{*}{ DUSA } & 1. & $54.66 \mathrm{AC}$ & $49.79 \mathrm{Ba}$ & $45.78 \mathrm{Ca}$ & $41.96 \mathrm{D}$ ab & $36,16 \mathrm{Ed}$ & \\
\hline & 3. & $63.66 \mathrm{~A}$ a & $4628 \mathrm{~B} \mathrm{~b}$ & $43.48 \mathrm{C} \mathrm{b}$ & $39.42 \mathrm{DC}$ & $30.93 \mathrm{Ee}$ & \\
\hline & 7. & $61.30 \mathrm{Ab}$ & $26.26 \mathrm{DC}$ & $21.79 \mathrm{EC}$ & $34.10 \mathrm{Cd}$ & $41.76 \mathrm{Bc}$ & \\
\hline & 14. & $59.76 \mathrm{~B}$ a & $15.77 \mathrm{D} \mathrm{d}$ & $11.89 \mathrm{Ed}$ & $40.16 \mathrm{C}$ bc & $49.86 \mathrm{~B} \mathrm{~b}$ & \\
\hline & 30. & $45.00 \mathrm{~B} \mathrm{~d}$ & $14.15 \mathrm{Cd}$ & $10.66 \mathrm{Da}$ & $43,50 \mathrm{~B} \mathrm{a}$ & $55.56 \mathrm{~A} \mathrm{a}$ & \\
\hline
\end{tabular}

SEKA çamuru için LSO $(\% 1): 0.150$

DUSA çamuru için LSD (\%1);0,116

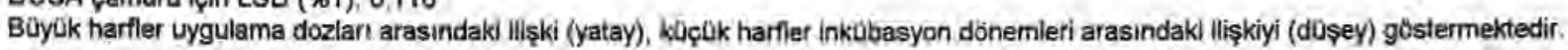

çamur dozu ilave edilmiş topraklarda dehidrogenaz aktivitesi ónemli olçude artı̧ gostermiştir $(P<0,05)$.

DUSA çamuru ilave edilmiş topraklarda da SEKA çamuru ilave edilmiş topraklara benzer sonuçlar elde edilmiş olup, inkübasyon suresi boyunca kontrol ve 20 ve 40 tonha camur ilave edilmiş topraklarda enzim aktivitesi azalmiştir. 80 tonha $^{-1}$ ve 160 tonha $^{-1}$ çamur dozu ilave edilmiş topraklarda da inkubasyonun ilk 7 gününde azalmalar gözlenmiş olup, inkübasyanun 7 . gününden itibaren ise, dehidrogenaz aktivitesi onemli ölçüde artış göstermiştir $(P<0.05)$.

Iki atık çamurunu kıyasıadığımızda, DUSA ve SEKA çamurları dehidrogenaz aktivitesini farklı etkilemiştir. Her iki çamurun yoksek dozlarda ilave edildiği topraklarda dehidrogenaz aktivitesi artış göstermiş olup, bu artışın DUSA çamurunda daha fazla olduğu belirlenmiştir. DUSA camuru ilave edilmiş topraklarda dehidrogenaz aktivitesi SEKA çamuruna göre daha fazla belirlenmiştir. DUSA çamuru llave edilmiş topraklarda inkabbasyonun 30 . gunonde 160 tonha $^{-1}$ camur dozunda dehidrogenaz aktivitesi 55.56 HgTPF $\mathrm{g}^{-t}$ olarak bulunmuşken, aynı inkobasyon süresi ve aynı dozda ilave edilmiş SEKA çamurunda aktivite $38.90 \mu \mathrm{gTPF} \mathrm{g}^{-1}$ olarak belirlenmiştir.

Arıtma çamuru ilave edilmiş topraklarda enzim aktivite dağılımı konusunda yapıimı araştimalara bakilacak olursa; Reddy ve Faza (1989), 0, 40, 80 ve 120 ton ha $^{-1}$ oranlarinda atık çamur llavelerinin toprakta dehidrogenaz aktivitesi ozerine etkilerini araştırdıklan çalıșmalanında, inkübasyonun llk 24 saatinde dehidrogenaz aktivitesinin arttığıni, 48 ve 72 saatlik inkübasyon dónemlerinde de aktivitenin artış gösterdiğini, atık çamur miktarinin artmasıyla aktivitede de azalma olduğunu belrtmişlerdir. Inkäbasyonun 96 , saatinde ise aktivitenin azalma gösterdiğini belirten araştirmacılar, yüksek dozlarda atık çamur ilave edilmiş topraklarda aktivitedeki önemli doșūşun camurlardaki ağırmetallerden kaynaklanabileceği gơrüşüno lleri sürmọşlerdir. Araştirmacilar ayni zamanda toprakta genel olarak mikrobiyal aktivitenin 72 saatlik inkübasyon süresinde maksimum noktaya ulaştığın, bu süreden sonre ise aktivitede azalmalann meydana geldiğini bellinmişlerdir.
Wilke (1991), ağır metallerin toprakta dehidrogenaz aktivitesi uzerine etkilerini araştırmış ve toprakta $\mathrm{Cd}, \mathrm{Ni}$ ve $Z_{n}$ varlığının 30 gün içinde dehidrogenaz aktivitesini onemil ölçüde $(P<0.05)$ azalttığını belirtmiştir.

Beyer ve ark. (1993), dehidrogenaz aktivitesinin toprakta mikrobiyal aktivite seviyesini yansıtmayan bazı ózel reaksiyonlarla ilişkili oldugunu ve bu reaksiyonların toprak redoks potanslyell, toprak su akış sistemi ve toprak havası olduğunu belirtmişlerdir. Araştırmacılar aynı toprak tipi, tekstor, $\mathrm{pH}$, organik $\mathrm{C}$ ve kile sahip topraklarda yukarida belintilen ozel reaksiyonların dehidrogenaz aktivitesini etkilediğini belirlemişlerdir.

Eivazi ve Zakaria (1993), aritma çamuru llave ettikleri topraklarda glikozidaz enzim aktivitesi tayin etmişler ve doşók dozlarda çamur ilavesinin enzim aktivitesini 30 gülak inkübasyon süresi boyunca ünemil düzeyde azalttiḡini ve yoksek dozlarda ilave edilen çamura bağlı olarak da aktivitenin arttığını belirlemişlerdir. Araştırmacılar llave edilen çamurun organik madde içeriğine ve doza bağlı olarak topraklarda enzim aktivitesinin değiştiğini, buna ilaveten de yäksek dozda çamur llavesi ile beraber aktivitelerde onemil artışların olduğunu belirlemişlerdir

Taşatar ve Haktanir (1997)'in DUSA ve SEKA çamurlan ile yaptikları araştırmalarında, çamur ilave edilmis topraklarda üreaz aktivitesi gamur dozuna bağli olarak 3 aylik Inkübasyon süresi boyunca artıs göstermiş ve DUSA çamurunda dreaz aktivitesi SEKA çamuruna oranla fazla bulunmuştur.

Bu araştırmada da iki farki nitellkteki çamurun dozuna ve çamur tipine bağlı olarak dehidrogenaz aktiviteleri değişim gostermiş olup, daha fazla organik madde ve azot içeren DUSA çamuru ilave edilmiş topraklarda dehidrogenaz aktivitesi SEKA çamununa oranla yôksek bufunmuştur. DUSA lie ortaya çıkan fazlalığın mineralize olabilir $\mathrm{N}$ ve $\mathrm{C}$ kapsamı ile ilgisi olabileceği dusşunulmektedir.

Ayrica daşuk dozlarda her iki çamur ilavesi sonucu dehidrogenaz aktivitesi inhibe olurken, yüksek dozlardaki çamur ilavesi sonucu inköbasyonun 7. gononden itibaren aktiviteler önemli olçode artiş gostermiştif. Artan daza 
bağlı olarak organik madde miktarında ve azot miktarindaki artişin çamurun içerdiği iz elementlerin (doza ve zamana bağlı olarak alınabilir $\mathrm{Pb}$ miktarında artış belirlenmiş olmasına rağmen) inhibasyon etkisini maskelemiş olabileceği ve çamurun llave edildiği toprakların da killi ve youksek katyon değişim kapasitesine sahip olmasından otörü ağır metalin etkisini azaltabileceği düşünümektedir. Bu görüşlerimiz Eivazi ve Zakaria (1993)'nin bulgulan ile paralellik göstermektedif.

Sonuç olarak araștırmada kullanilmış olan arıtma çamuru örnekleri uluslararası standartlara göre, çok daşük miktarlarda alınabilir $\mathrm{Pb}$ içermektedir. Ancak bu materyal yüksek miktarda organik madde ve besin elementi içerdiğinden, gübre olarak kullanıima olasıliğı bulunmaktadir. Fakat camur orneklerinin, topraklara ilavesi sonucu $\mathrm{Pb}$ birikimine neden olabileceği ve bu birikimin çamurun uzun yillar ilavesi lie birlikte artacağı, bunun da bitki, hayvan ve insanlar için tehlike teşkil olușturabileceği soylenebilir.

\section{Kaynakiar}

Akça, L., Çilii, E. ve N Tölekçi, 1998. Arıtma çamurlarınin tarım alanlarında deǧerlendirilmesi. Tarım-Çevre lișkileri Sempozyumi, 35-42, Mersin:

Akther, M. S. 1990. Trace metal analysis of sewage siudge and soils in Bahrain. Water, air and soil Pollution, 51, 147-152.

Al-Khafaji, $A, A$, and M. A. Tabatabal, 1979. Effects of trace elements on arylsulfatase activity in soils. Soil Sci., 127,129133

Beyer, L. Wachendorf, C., Elsner, D.C. and R. Knabe, 1993. Suitability of dehydrogenase activity assay as an index of soil biological activity. Biol. Fertil. Soils., 16, 52.56.

Blum, W. E. H. 1989, Soil pollution by heavy metals: causes, processes, impacts and need for future actions: In: Proceedings of third meeting. Steering Committee for the conservation and management of the environment and naturals habitats (CDPE), Strasbourg.

Bond, $H_{1}$, Lightheart, B., Shimabuku, R. and L. Russell, 1976. Some effects of Cd on coniferous forest soil and litter microcosms. Soil Sci., 221, 278-287.

Bouyoucos, G. J, 1951. Are Calibration of the Hidrometre for Making Mechanical Analysis of Solls. Agronomy Journal, 43,9 .

Bremner, d. M. 1965. "Total Nitrogen". In Methods of Soil Analysis 2; (C.a. Black, Ed), 1145-1178. Amirecan Society of Agronomy, Madison, Wis.

Börekçi, M. 1991, Türkłye topraklannda KOK ile deḡişebilir topraklarin tayininde uygulanacak metodlar. T.C. Tarim ve Köyișleri Bak., Käy Hizmetleri Genel Müdürlügü, Toprak ve Gubre Araștırma Ens. Md. 174, 37-40, Ankara,

Çağlar, K.Ü. 1958, Toprak limi, A.U. Ziraat Fak. No. 241, Ankara.

De Boodt, M, Verdonck, O. and I. Cappaert, 1973. Method of meausring the water release curve of organic substrates. Proceeding Symposium Artifical Media in Horticulture. 2054 2062.
Eivazi, $F$ and A. Zakaria, 1993. $\beta$-Glucosidase activity in soils amended with sewage sludge. Agriculture, Ecosystems and Environment. 43-155-161

Elvazi, F, and M. A. Tabatabai, 1990. Factors effecting glucosidase and galactosidase activities in soils. Soil Biol. Biochem. 22(7), $891-897$.

Eroğlu, V., Bașturk, A, Dalarslan, C. Atun, $F$ ve Sakiroğlu, N 1990. SEKA Izmit milessesesi atıksu tasfiye tesisi çamuitarinın biyolojik metodlarla bertarafi ITÜ 2, Endüstriyel Kirlenme Sempozyumu, Istanbul.

Frankberger, Jr. W. T. and M. A. Tabatabai, 1981, Amidase activity in soils. $V$, effects of trace elements and pesticides. Soil Sel. Soc. Am., 45-120-124

Frankberger, Jr. Johanson, W. T and C. O. Nelson, 1983, Urease activity in sewage sludge amended soils. Soil Biol. Biochem, $15(5), 543-549$.

Geveci, A. 1995. DUSA Endustriyel Iolik Sanayl ve Tic. A.S.'nin çarnur analiz raporu. Cevre Müh, Bölümü, TÜBITAK Marmara Araştirma Merkezi, Kocaeli.

Jackson, M. L. 1962, Soil Chemical Analysis, Prentice Hall inc. Eng. Cliffs. U.S.A

Juma, N. G. and M. A. Tabatabai, 1977. Effects of trace elements on phosphatase activity in soils. Soil Sci. Soc, Am., 41, 343346.

Kacar, B. 1990. Gübre analizleri. A.Ú Ziraat Fak. Eğitim Araştırma Geliş. Vakfi Yayını Ankara.

Kacar, B. 1996. Bitki ve toprag̉in kimyasal analizieri. A. D.Ziraat Fak Eğitim Araștırma Geliş. Vakfi Yayını, no. 3, 223-225, Ankara.

Karpuzcu, M. 1991. Cevre kirlenmesi ve kontrolu. Boğaziç Oniversitesi, Çevre Bilim. Enst. Yayiniarı, Istanbuil.

Liang, C. N. and M. A. Tabatabai, 1977. Effects trace eiements on nitrogen mineralization in solls. Environ. Pollut., 12, 141-147,

Lindsay, W. L and Norwell, W. A.1 1978. Development of a DTPA Soil Test for $\mathrm{Zn} F \mathrm{Fe}, \mathrm{Mn}$ and $\mathrm{Cu}$. Soil Sci. Soc. Am. J. 42 , $421-428$.

Naplekova, N. N and Bulavko, G. I. 1983, Enzyme Activity of Solis Polluted by Lead Compounds. Soviet Soil Sci. 15: 33-38.

O'Riordan, E, G, Dodd, V, A and Fleming., G, A, 1994. Spreading a loow metal sludge on grassland: Effects on soil and herbage heavy metal concentrations. Irish $\mathrm{J}$. of Agricullural and Food Research. 33, 61-69.

Perez-Mateos, M. and Gonzalez-Carcedo, S. 1987, Effect of Cadmium and Lead on Soil Enzyme Activity. Rev. Ecol. Biol Sol: 1: $11-18$

Reddy, G. B. and Faza, A. 1989. Dehydrogenase activity in sludge amended soil. Soil Biol. Bioch. 21, 327

Richards, L. A. 1954. Diagnosis and Improvement of Saline and Alkali Soils. U.S.D.A. Handbook 60

Richards, L, A. 1949. Methods of measuring soll moisture tansion. Soil Sci, $68,95-112$ 
Rogers, J. E. and Li, S. W. 1985. Effect of Metals and Other Inorganic Ions on Soil Microbial Activity: Soil Dehydrogenase Assay as a Simple Toxicity Test. Bull. Environ. Contam. Toxicol. 34: 858-865.

Tabatabai, M. A. 1977. Effects of trace elements on urease activity in soils. Soil Biol. Bioch. 9, 9-13.

Taşatar, B. ve K. Haktanır, 1997. Endüstriyel nitelikli arıtma çamurlarının bazı toprak özellikleri üzerine etkileri. Doktora tezi, A.Ü.Fen Bilimleri Enstitüsú, Ankara.
Turalıŏlu, S. ve E. Erdin, 1990. Sanayi kökenli arıtma çamurunun arazide bertarafı. ITÜ 2. Endüstriyel kirlenme sempozyumu, istanbul.

Wilke, B. M. 1991. Effects of single and successive additions of Cd, $\mathrm{Ni}$ and $\mathrm{Zn}$ on $\mathrm{CO}_{2}$ evolution and dehydrogenase activity in a sandy luvisol, Biol. Fertil. Soils, 11, 34-37.

Williams, D. E., Vlaims, J., Pukite, A. H. and J. E. Corey, 1987. Metal movement in sludge amended soils: A nine year study. Soil Sci. 143 (2), 124-131. 